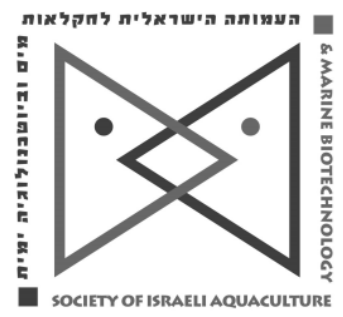

The IJA appears exclusively as a peer-reviewed on-line open-access journal at http://www.siamb.org.il. To read papers free of charge, please register online at registration form.

Sale of IJA papers is strictly forbidden.

\title{
Aeromonas hydrophila induces apoptosis in pufferfish, Takifugu obscurus
}

\section{Chang-Hong Cheng ${ }^{1}$, Zhi-Xun Guo ${ }^{1, *}$, An-Li Wang ${ }^{2, *}$}

${ }^{1}$ Key Laboratory of Aquatic Product Processing, Key Laboratory of South China Sea Fishery Resources Exploitation \& Utilization, Ministry of Agriculture, South China Sea Fisheries Research Institute, Chinese Academy of Fishery Sciences, Guangzhou, Guangdong 510300, China

${ }^{2}$ Key Laboratory of Ecology and Environmental Science of Guangdong Higher Education Institutes, Guangdong Provincial Key Laboratory for Healthy and Safe Aquaculture, School of Life Science, South China Normal University, Guangzhou 510631, People's Republic of China

Keywords: Takifugu obscurus; Aeromonas hydrophila; apoptosis; caspase-3

\begin{abstract}
Aeromonas hydrophila is a Gram-negative opportunistic pathogen causing motile aeromonad septicemia, which results in great economic losses in freshwater fish farming. In this study, we investigated the effect of $A$. hydrophila on apoptosis of pufferfish blood cells. Total blood cell count, reactive oxygen species (ROS) production, cytoplasmic free-Ca ${ }^{2+}$ $\left(\mathrm{cf}-\mathrm{Ca}^{2+}\right)$ concentration, nitric oxide (NO) production, apoptotic cell ratio and the transcription levels of caspase- 3 in the pufferfish blood cells were determined after $A$. hydrophila infection. Results showed that $A$. hydrophila infection significantly depressed the total blood cell count, and significantly increased ROS production, $\mathrm{cf}^{-\mathrm{Ca}^{2+}}$ concentration, NO production and apoptotic cell ratio. The transcription levels of caspase- 3 increased significantly after $A$. hydrophila infection. Taken together, our results suggest that $A$. hydrophila infection alters $\mathrm{ROS}, \mathrm{cf}-\mathrm{Ca}^{2+}, \mathrm{NO}$ levels, and active caspase-3, which lead to cell apoptosis.
\end{abstract}

\footnotetext{
*Corresponding author 1: G.Z.Guo: email address: guozhixun1@163.com Corresponding author 2: A. Wang: email address: wanganl@scnu.edu.cn
} 


\section{Introduction}

Aeromonas hydrophila is a Gram-negative opportunistic pathogen widely distributed in aquatic environments (Majumdar et al., 2009). This bacterium is a part of normal intestinal bacterial flora of the fish and is able to cause disease through the effect of stress (Ardó et et al., 2010). It causes motile aeromonad septicemia (MAS), which results in severe economic losses to the aquaculture industry worldwide (Sahu et al., 2007; Xu et al., 2012). The symptoms of $A$. hydrophila infection include anorexia, exophthalmos, dropsy, red sores, necrosis, and ulceration (Shen et al., 2013). Moreover, this bacterium can also behave as secondary opportunistic pathogens by assailing already compromised or stressed hosts (Tellez-Bañuelos et al., 2010). It can produce several virulence factors, including hemolysins, protease, leucocidins, endotoxins, and adhesions, which are all thought to contribute to the overall development of the disease in fish (Majumdar et al., 2009; Banerjee et al., 2012).

Apoptosis, also called programmed cell death, is a common physiological process that evolved in eukaryotes to remove surplus, infected, or damaged cells to maintain the integrity of the organism (Du et al., 2013). It plays a critical role in the development, cellular homeostasis, and immune responses of multicellular organisms. However, either uncontrolled apoptosis or its non-occurrence is involved in the pathogenesis of a variety of important disease processes including cancer, HIV infection, acute inflammatory disease, and autoimmunity (Thompson, 1995; Shao et al., 2004). Apoptosis also plays an important role in various bacterial diseases (Weinrauch and Zychlinsky, 1999). Induction of apoptosis in host cells appears to be part of strategies by which pathogenic bacteria modulate the immune response of the host (Moine and Abraham, 2004; Majumdar et al., 2009). A. hydrophila induces apoptosis in fish (Shao et al., 2004; Banerjee et al., 2012). However, the relationship between cell apoptosis and pathogenesis of fish bacterial diseases is still unclear.

Like other animals, fish blood also plays an essential role in physiology and immune defense (Vázquez and Guerrero, 2007). Nonspecific and specific immunity in fish has been positively correlated with the number of red and white blood cells. Therefore, total blood cell count may be a convenient indicator of fish physiological status. Damage to blood organs in fish supress immune ability and even endanger organism survival. $A$. hydrophila infection decreased the blood cell numbers and modulated the innate immune factors in olive barb (Das et al., 2011).

Reactive oxygen species (ROS) are commonly used as messenger molecules in normal cell functions. However, overproduction of ROS may lead to oxidative damage to tissue macromolecules including DNA, proteins, and lipids (Wang et al., 2009), and subsequently induce cell apoptosis (Circu and Aw, 2010). Calcium has been recognized as an important secondary messenger for a variety of cellular processes. Oxidative stress causes a $\mathrm{Ca}^{2+}$ influx into the cytoplasm from the extra-cellular environment, and the endoplasmic reticulum or sarcoplasmic reticulum (ER/SR) through the cell membrane, and the ER/SR channels, respectively (Wang et al., 2009). $\mathrm{Ca}^{2+}$ overload or disturbances in local intracellular distribution lead to cell death (Orrenius et al., 2003). Nitric oxide (NO) has been identified as a vital physiological modulator and signaling molecule in both mammals and fish (Acosta et al., 2004). The dysregulation or overproduction of NO has been involved in immune system damage and cell apoptosis (Kim et al., 2001).

River pufferfish Takifugu obscurus, widely distributed in the Sea of Japan, the East China Sea, and the Yellow Sea, is an anadromous fish. Because of the relatively small size and simple organization of its genome, Takifugu is used as a model organism to understand peculiar physiology, morphology, and genomics (Aparicio et al., 2002). In recent years, farmed pufferfish have become increasingly popular in Chinese markets due to their rapid growth and high 
nutritional quality. However, pufferfish culture suffers from serious disease problems caused by bacterial pathogens. In this study, we investigated the effects of $A$. hydrophila infection on total blood cell count, ROS production, cytoplasmic free- $\mathrm{Ca}^{2+}$ concentration, NO production, apoptotic cell ratio, and the transcription levels of caspase- 3 in pufferfish. This study can help to further understand the mechanism of cell apoptosis in response to bacterial infection.

\section{Materials and methods}

Pufferfish (average body weight $11.80 \pm 0.43 \mathrm{~g}$ ) were supplied by a fish farm in Panyu (Guangdong, China). The fish were kept in 250L cycling-filtered plastic tanks containing continuously circulating aerated water at $25 \pm 1^{\circ} \mathrm{C}(\mathrm{pH} 7.5 ; 6.2$ $\mathrm{mg} / \mathrm{L}$ dissolved oxygen) for two weeks before experimental treatments. During the acclimation period, the commercial fish diet (42\% protein, $8.0 \%$ fat, $5.0 \%$ fiber and $15 \%$ ash, supplied by a commercial diet, China) was fed twice a day at a rate of $3 \%$ wet body weight.

Aeromonas hydrophila ( $A$. hydrophila) was obtained from diseased pufferfish. The isolate was confirmed as $A$. hydrophila after biochemical and molecular identification. A. hydrophila was cultured in Lysogeny broth (LB medium) at $28^{\circ} \mathrm{C}$ for $12 \mathrm{~h}$. The bacterial cells were collected by centrifugation (3000 rpm, $10 \mathrm{~min}$ ) and washed twice with phosphate-buffered saline (PBS). The bacteria were then resuspended in PBS. Fish were infected with a 50\% 72-h $L_{50}$ dose of bacteria $\left(1 \times 10^{7} \mathrm{CFU} / \mathrm{ml}\right)$. One hundred and sixty fish were randomly divided into two groups ( 80 individuals/group) the control group, and the treatment group. Each fish in the treatment group was injected intraperitoneally with $100 \mu \mathrm{l}$ of suspended bacteria, while the control group was injected with the same volume of PBS. At $0,3,6,12,24,48$, and $72 \mathrm{~h}$, six fish from each group were randomly sampled and dissected after anesthesia in $0.05 \%$ tricaine methane sulfonate (MS222, Sigma Diagnostics INS, St. Louis, MO) respectively. Blood samples were taken from the heart using a sterilized syringe containing an anticoagulant solution and immediately transferred into an individual tube held on ice to measure total blood cell count, oxygen species (ROS) production, cytoplasmic free- $\mathrm{Ca}^{2+}\left(\mathrm{cf}^{-\mathrm{Ca}^{2+}}\right)$ concentration, intracellular nitric oxide (NO) production, and apoptotic cell ratio (see below).

A drop of diluted blood sample $(10 \mu \mathrm{L})$ was placed on a hemocytometer and counted under a light microscope (Olympus).

To monitor the level of respiratory burs, the cell-permeant probe $2^{\prime}, 7^{\prime}$ dichlorofluorescein diacetate (DCFH-DA, Sigma) was used as described by Xian et al.(2009). A volume of $200 \mu \mathrm{L}$ blood cells suspension was incubated with $10 \mu \mathrm{M}$ DCFH-DA for $30 \mathrm{~min}$ in the dark at room temperature. Then the fluorescence of the cell suspensions was analyzed using the flow cytometer (Becton-Dickinson FACSCalibur). Typically, 10,000 cells were analyzed for the two fluorescent signals. ROS production was expressed as mean fluorescence of DCF.

The $\mathrm{cf}-\mathrm{Ca}^{2+}$ concentration in the current experiment was examined using the previously described method (Xian et al., 2010). A volume of $200 \mu \mathrm{L}$ blood cells suspension was incubated with $10 \mu \mathrm{M}$ fluo-3/AM for $30 \mathrm{~min}$ in the dark. Then the fluorescence of the cell suspensions was analyzed by flow cytometer.

The fluorescent probe 4-amino-5-methylamino- $2^{\prime}, 7^{\prime}$ - difluorofluorescein diacetate (DAF-FM DA, Sigma) was used to measure intracellular NO production. DAF-FM DA solutions were prepared by dissolving DAF-FM DA in dimethyl sulphoxide (DMSO, Sigma Diagnostics INS, St. Louis, MO) to $1 \mathrm{mM}$ and stored at $20^{\circ} \mathrm{C}$. $200 \mu \mathrm{L}$ blood cell suspension was incubated with $10 \mu \mathrm{M}$ DAF-FM DA for 60 min at room temperature in the dark, then the DAF-FM fluorescence of cells was recorded on FL1 by detector of flow cytometer. NO production was expressed as mean fluorescence of DAF-FM in arbitrary units (A.U.).

The apoptosis of blood cells were determined with Annexin V-FITC and propidium iodide (PI) staining using an apoptosis detection kit (Invitrogen) 
following the manufacturer's instructions. The collected blood cells were diluted with anticoagulant solution to obtain a final concentration of $1 \times 10^{6}$ cells. The pellets were resuspended by Annexin V-FITC binding buffer, and then incubated with Annexin V-FITC in the dark at $20-25^{\circ} \mathrm{C}$ for $10 \mathrm{~min}$. Samples were then analyzed by a flow cytometer.

Total RNA was extracted using TRIzol reagent (Invitrogen, USA) according to the manufacturer's instructions. The A260/280 ratios of all the RNAs prepared were measured by Nanodrop 2000 spectrophotometer (Nanodrop Technologies, Wilmington, DE, USA). RNA integrity was checked by electrophoresis on $1 \%$ agarose gels. Single-stranded cDNA was synthesized from $1 \mu \mathrm{g}$ total RNA using PrimeScript RT reagent Kit With gDNA Eraser (Takara, Dalian, China) following the manufacturer's instructions. cDNA templates were then stored at $-80^{\circ} \mathrm{C}$ for later analysis.

mRNA expression levels of caspase- 3 in blood cells after bacterial innoculation were measured by quantitative real time RT-PCR. Information of gene specific primers used for real-time PCR is given in Table 1. Pufferfish beta actin was selected as a house keeping gene in this study. Before the qRT-PCR experiments, the specificity and efficiency of the primers above were detected. Real-time PCR was amplified in an ABI 7500 real-time PCR machine (Applied Biosystems, USA) using SYBR Premix Ex TaqTM (Takara, Dalian, China) following the manufacturer's recommendations. Reaction mixtures were $20 \mu \mathrm{L}$, containing $2 \mu \mathrm{L}$ cDNA sample, $0.4 \mu \mathrm{L}$ ROX, $10 \mu \mathrm{L} 2 \times$ SYBR Premix Ex Taq, $0.4 \mu \mathrm{L}$ each of the 10

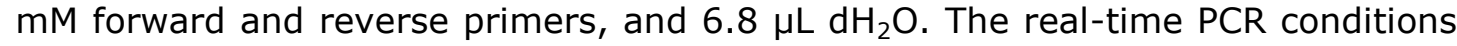
were as follows: $94^{\circ} \mathrm{C}$ for $10 \mathrm{~min}$, then $45 \mathrm{cycles}$ at $95^{\circ} \mathrm{C}$ for $30 \mathrm{~s}, 60^{\circ} \mathrm{C}$ for $30 \mathrm{~s}$ and $72^{\circ} \mathrm{C}$ for $30 \mathrm{~s}$, followed by $10 \mathrm{~min}$ at $72^{\circ} \mathrm{C}$. After the program was completed, the threshold cycle $(\mathrm{Ct})$ values were obtained from each sample. Relative gene expression levels were evaluated using $2^{-\Delta \Delta C T}$ method (Livak and Schmittgen, 2001)

Table 1. The sequences of primers in this experiment.

\begin{tabular}{llll}
\hline $\begin{array}{l}\text { Target } \\
\text { gene }\end{array}$ & Primer sequence $\left(5^{\prime}-3^{\prime}\right)$ & Gen Bank & $\begin{array}{l}\text { Amplicon size } \\
(\mathrm{pb})\end{array}$ \\
\hline Caspase 3 & $\begin{array}{l}\text { F:CGAGGGCGTGTTTTTGGT } \\
\text { R:GGGATCTTGGTGGTGCTGC }\end{array}$ & NM_001032699.1 & 135 \\
B-Actin & $\begin{array}{l}\text { F:CATCACCATCGGCAACGAGAGG } \\
\text { R:CGTCGCACTTCATGATGCTGTTG }\end{array}$ & AJ715484.1 & 115 \\
& & \\
\hline
\end{tabular}

All data are expressed as means \pm standard deviation. Significant differences were evaluated by a one-way ANOVA followed by Duncan's multiple range tests. Statistical analysis was performed using SPSS 18.0 software (SPSS, Chicago, IL, USA). $P$ value $<0.05$ was considered to be statistically significant.

\section{Results}

Blood cell numbers after bacterial infection are shown in Fig. 1. At the beginning, the mean blood cell count was $122.7 \times 10^{7} \mathrm{cells} / \mathrm{ml}$. After bacterial infection, the blood cell count decreased significantly at 3, 6, 12, 24, 48 and $72 \mathrm{~h}$. The lowest level of blood cell count was observed at $48 \mathrm{~h}$ post-infection.

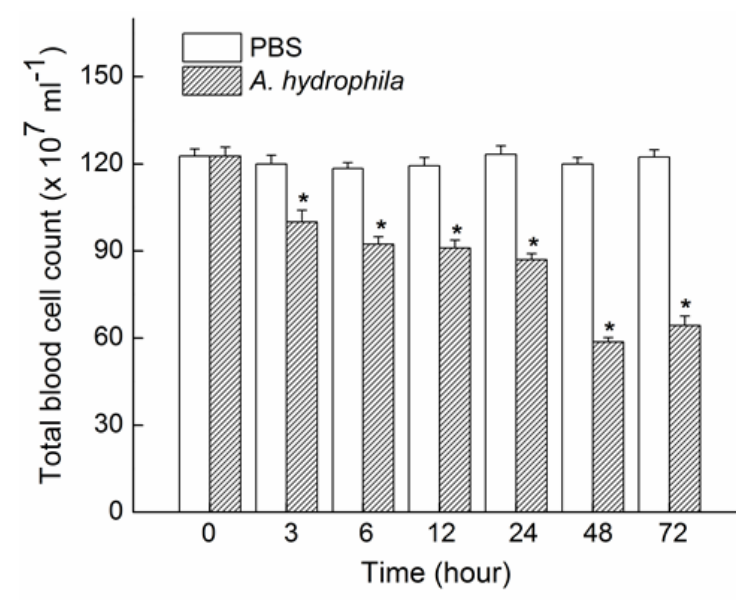

Fig.1. Total blood cell count of pufferfish in response to $A$. hydrophila infection.

ROS levels in blood cells are shown in Fig. 2. ROS production increased significantly at $3 \mathrm{~h}$ after bacterial infection $(P<0.05)$. Moreover, the highest ROS levels were observed at $72 \mathrm{~h}$ post-infection. 


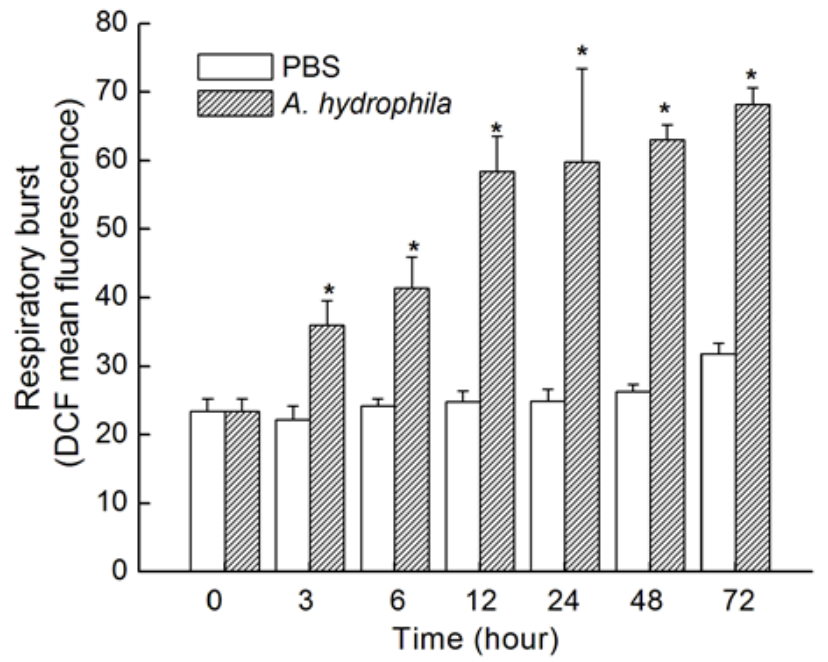

Fig.2. Respiratory burst activity in the blood cells of pufferfish in response to $A$. hydrophila infection.

As shown in Fig. 3, there were no significant differences in $\mathrm{cf}-\mathrm{Ca}^{2+}$ concentration at $3 \mathrm{~h}$ and $6 \mathrm{~h}$ post-infection.

$\mathrm{Cf}-\mathrm{Ca}^{2+}$ concentration increased significantly at 12 $h$, and then increased further to a high level at $48 \mathrm{~h}$, but then decreased (more than the control) until the end of the experiment.

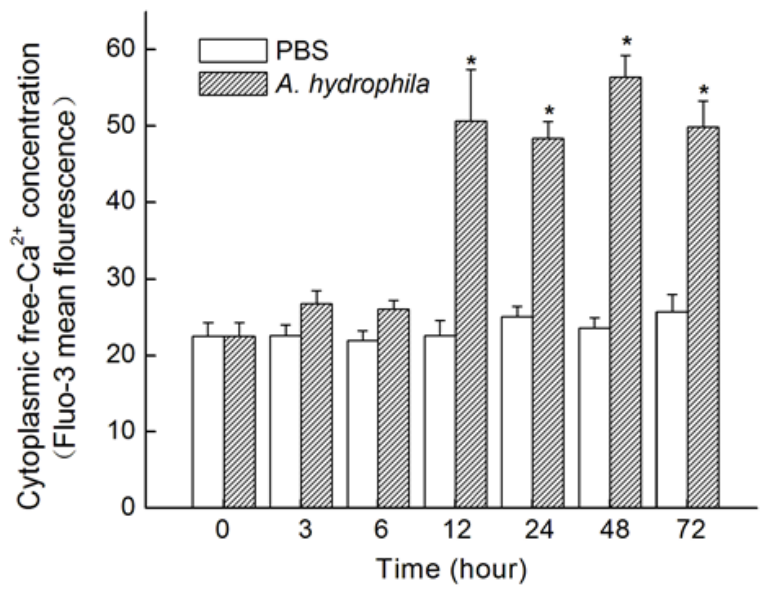

Fig.3. Nitric oxide production in the blood cells of pufferfish in response to $A$. hydrophila infection.

The changes of the NO production after bacterial infection were shown in Fig. 4. NO production increased significantly at 3, 6, 12, 24, 48 and $72 \mathrm{~h}$ after bacterial infection. The highest production of NO was observed at $72 \mathrm{~h}$ postinfection.

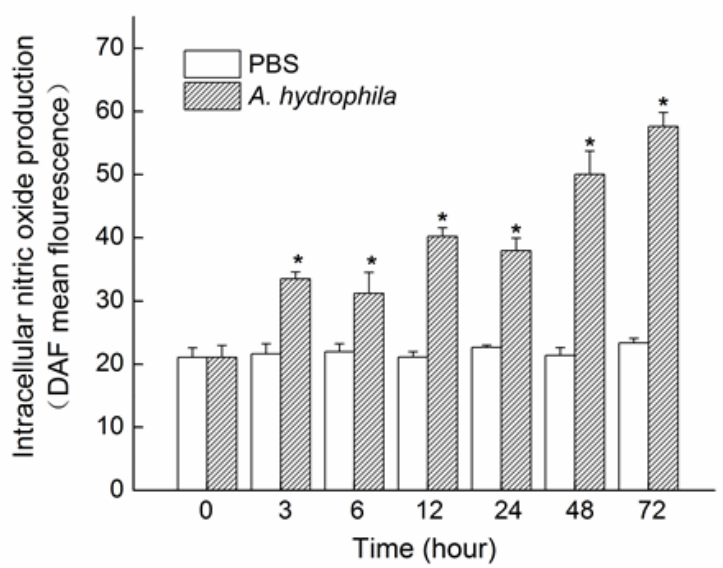

Fig.4. Cytoplasmic free-Ca ${ }^{2+}$ concentration in the blood cells of pufferfish in response to $A$. hydrophila injection. 

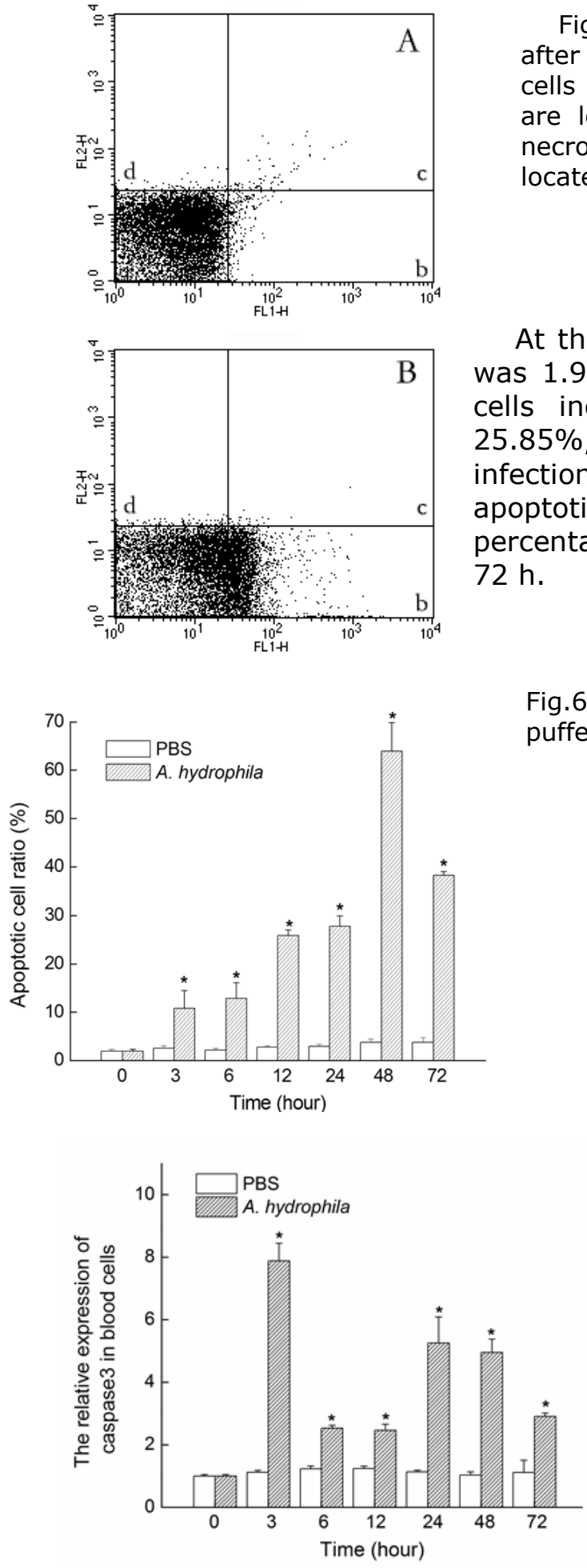
$72 \mathrm{~h}$.
Fig.5. Apoptosis dot plot of blood cells of pufferfish after $0 \mathrm{~h}$ (A) and $72 \mathrm{~h}$ (B) $A$. hydrophila infection. Live cells are located in quadrant (a). Early apoptotic cells are located in quadrant (b). Late apoptotic cells and necrotic cells are located in quadrant (c). Cell debris is located in quadrant (d).

At the beginning, the percentage of apoptotic cell was $1.91 \%$ (Fig. 5, 6). Apoptotic cell ratio of blood cells increased significantly to $10.82 \%, 12.84 \%$, $25.85 \%$, and $27.74 \%$ at $3,6,12$ and $24 \mathrm{~h}$ postinfection, respectively. The highest percentage of apoptotic cell $(63.92 \%)$ was observed at $48 \mathrm{~h}$. Then, percentage of apoptotic cell decreased to $38.21 \%$ at

Fig.6. Percentage of apoptotic cell in the blood cells of pufferfish in response to $A$. hydrophila infection.

Fig.7. Expression of the caspase-3 transcript at $0,3,6,12,24,48$ and $72 \mathrm{~h}$ after $A$. hydrophila injection in the blood cells.

The change of caspase- 3 transcription was investigated after innoculation with bacteria. As shown in Fig. 7, the caspase-3 transcription levels were significantly up-regulated after bacterial infection. The highest expression fold in response to bacterial challenge occurred at $3 \mathrm{~h}$ (7.9-fold).

\section{Discussion}

Aeromonas hydrophila is distributed widely in aquatic environments and can infect terrestrial animals and a variety of farmed fish. It is a causative agent of motile aeromonad septicemia. Disease outbreaks usually occur when fish are immune-comprised by stresses from overcrowding, low oxygen, high temperature or concurrent diseases (Stevenson, 1988; Shao et al., 2004). Previous study demonstrated that $A$. hydrophila induced apoptosis in fish as well as in 
mammalian cells (Shao et al., 2004). Little is known about the relationship between cell apoptosis and pathogenesis of fish bacterial diseases. In the present study, we investigated the effects of $A$. hydrophila infection on total blood cell count, oxygen species (ROS) production, cytoplasmic free- $\mathrm{Ca}^{2+}\left(\mathrm{cf}^{2} \mathrm{Ca}^{2+}\right)$ concentration, intracellular nitric oxide (NO) production, apoptotic cell ratio, and the transcription levels of caspase- 3 in pufferfish.

Blood is an important indicator for immune function and oxygen transportation (Vázquez and Guerrero, 2007; Singh and Srivastava, 2010). Decrease in blood cell numbers might lead to impaired immune capability, decreased resistance to bacterial infection, and ultimately death ( Li et al., 2014). A. hydrophila infection has been reported to result in decreased blood cell count in fish (Das et al, 2001). In this study, a sharp decrease of the blood cell count was observed after $A$. hydrophila infection. Decreased blood cell count may lead to impaired immune capability and ultimately death.

The release of ROS by blood cells is a critical step in the innate immune response by which potential pathogens and parasites are eliminated following phagocytosis (Xian et al, 2010). Under normal conditions, mild increase in ROS is considered to be beneficial with respect to increased immunity. However, high ROS such as hydrogen peroxide $\left(\mathrm{H}_{2} \mathrm{O}_{2}\right)$, free radicals superoxide $\left(\mathrm{O}_{2} \bullet^{-}\right)$and hydroxyl radical $(\mathrm{HO} \bullet)$ can be important mediators of damage to the host cell ( $\mathrm{Qi}$, et al, 2013). Previous study has showed that infections and diseases increase the production of ROS which may damage important biomolecules, such as DNA, proteins and lipids (Halliwell, 1993). Moreover, ROS is an important factor in apoptotic processes and acts as key agents in the events leading to neurodegeneration, such as caspase activation, glial activation, mitochondrial dysfunction, protein misfolding, and proteasomal disregulation (Andersen, 2004; Wang, et al, 2008). In our study, ROS level of blood cells after bacterial infection was significantly higher than that of the control group. This result suggested that bacterial infection could induce excessive ROS production.

As an important second messenger, calcium signaling is known to be involved in regulating a variety of cellular processes. $\mathrm{Ca}^{2+}$ signaling may also modulate many physiological or pathological processes including apoptosis (Xian, et al, 2013). Some previous studies have shown that an increase in cytosolic $\mathrm{Ca}^{2+}$ may lead to apoptosis due to stimulation of intracellular protease(s), nucleases, phospholipases, and other hydrolytic enzyme activities (Orrenius, 2003; Chen, et al, 2006). It has been shown that an increase of $\mathrm{cf}^{-\mathrm{Ca}^{2+}}$ concentration may be stimulated by ROS (Rizzuto et al., 2003). In this study, $\mathrm{cf}^{-\mathrm{Ca}^{2+}}$ concentration increased significantly at $12 \mathrm{~h}$ after bacterial infection. The possible role of calcium in $A$. hydrophila-induced apoptosis has also been reported in fish cells (Banerjee et al., 2012). These alterations in $\mathrm{cf}^{-\mathrm{Ca}^{2+}}$ concentration were consistent with elevated production of ROS. This result suggested that $\mathrm{cf}^{-\mathrm{Ca}^{2+}}$ may be an apoptotic signal mediator, playing a major role in the mechanism of programmed death induced by bacterial infection.

NO is a multifunctional free radical generated by three different forms of nitric oxide synthases (NOS): inducible NOS (iNOS), neuronal NOS (nNOS), and endothelial NOS (eNOS) (Pavanelli et al., 2010; Jin et al., 2011). It has been reported that NO is produced via the induction of iNOS by macrophages in response to outside stimuli (Tafalla et al., 2005). Previous studies suggested that the overproduction of NO was involved in cell apoptosis (Kim et al., 2001; Lu et al., 2003). To initiate apoptosis, NO can induce mitochondrial dysfunction by stimulating membrane permeability transition thus activating a cascade of reactions leading to cell death (Marriott et al., 2004; Wang et al., 2008). In our study, we observed that NO production increased significantly $3 \mathrm{~h}$ after bacterial infection. This result suggested that bacterial infection could change NO production. 
Mitochondria are one of the most important organelles in apoptosis (Christophe et al., 2002). Mitochondrial alterations such as loss of transmembrane potential, production of ROS, disruption of the electron transport chain, and decrease in ATP synthesis are tightly related to apoptosis (Xiang et al., 2008). Activation of the apoptosis process can enhance immune defense by limiting the spread of pathogens, and preventing inflammatory damage of surrounding tissues (Mai et al., 2010). In this study, the apoptotic blood cells were examined using flow cytometer. Apoptotic cell ratio increased significantly after $A$. hydrophila infection. This result had a high correlation with increased ROS, $\mathrm{cf}-\mathrm{Ca}^{2+}$, and NO production. Therefore, our results further suggested that bacterial infection could cause a variety of disorders in the blood system and trigger apoptotic and necrotic cell death.

Apoptosis is modulated by the extrinsic or intrinsic apoptotic pathways that involve a series of biochemical regulators and molecular interactions (Bridgham et al., 2003; Wang et al., 2008). The central molecules of apoptosis are the caspases. Both extrinsic and intrinsic apoptotic pathways result in the activation of caspase-3, which is a major executioner of apoptosis in the apoptotic pathway (Li et al., 2011). Activation of caspase-3 causes many of the characteristic morphological alterations of apoptosis, such as breakdown of several cytoskeletal proteins, and degradation of the inhibitor of caspase-activated DNAses, directing the cell toward death (Cohen 1997; Elvitigala et al., 2012). In the present study, we observed the ascension caspase- 3 activity after $A$. hydrophila innoculation, suggesting that $A$. hydrophila could induce caspase-dependent apoptosis in pufferfish blood cells.

In conclusion, the present study demonstrated that $A$. hydrophila infection altered ROS, NO and $\mathrm{cf}-\mathrm{Ca}^{2+}$ levels, and activated caspase-3, which then led to cell apoptosis. The information presented in this study will help to elucidate the precise mechanism of cell apoptosis in response to bacterial infection.

\section{Acknowledgements}

This research was supported by Special Funds for Fish Diseases of Guangdong province (2015-352 and 2016-302), Marine Fisheries Technology and Industry Development Special Projects of Guangdong Province (A201501B14), Marine Fisheries Science and Technology Extension Projects of Guangdong Province (B201601-11), Science and technology Projects of Guangdong Province (2014B040404057).

\section{References}

Acosta F., Galarreta C.M., Ellis A.E., Díaz R., Gómez V., Padilla D., Real F., 2004. Activation of the nitric oxide response in gilthead seabream after experimental infection with Photobacterium damselae subsp. piscicida. Fish Shellfish Immun, 6:581-588.

Andersen J.K., 2004. Oxidative stress in neurodegeneration: cause or consequence? Nat Rev Neurosci, 5:S18-S25.

Aparicio S., Chapman J., Stupka E., Putnam N., 2002. Whole-genome shotgun assembly and analysis of the genome of Fugu rubripes. Science, 23:1301-1310.

Ardó I., Jeney Z., Adams, A., Jeney G., 2010. Immune responses of resistant and sensitive common carp families following experimental challenge with Aeromonas hydrophila. Fish Shellfish Immun, 29:111-116.

Banerjee C., Goswami R., Verma G., Datta M., Mazumder S., 2012. Aeromonas hydrophila induced head kidney macrophage apoptosis in Clarias batrachus involves the activation of calpain and is caspase-3 mediated. Dev. Comp. Immunol, 37:323-333. 
Bridgham J., Wilder J., Hollocher H., Johnson A.,2003. All in the family: evolutionary and functional relationships among death receptors. Cell Death Differ, 10: 19-25.

Chen X.Y., Shao J.Z., Xiang L.X., Liu X.M., 2006. Involvement of apoptosis in malathion-induced cytotoxicity in a grass carp (Ctenopharyngodon idellus) cell line. Comp. Biochem. Phys. C. 142:36-45.

Christophe F., Bernard M., Jean L.V., 2002. Mitochondrial reactive oxygen species in cell death signaling. Biochimie, 84:131-141.

Circu M.L,, Aw T.Y., 2010. Reactive oxygen species, cellular redox systems, and apoptosis. Free Radic. Biol. Med, 48:749-762.

Cohen G.M., 1997. Caspases: the executioners of apoptosis. Biochem. J 326:116.

Das A., Sahoo P.K., Mohanty B.R., Jena J.K., 2011. Pathophysiology of experimental Aeromonas hydrophila infection in Puntius sarana: Early changes in blood and aspects of the innate immune-related gene expression in survivors. Vet. Immunol. Immunop. 142: 207-218.

Du Z.Q., Lan J.F., Weng Y.D., Zhao X.F., Wang J.X., 2013. BAX inhibitor-1 silencing suppresses white spot syndrome virus replication in red swamp crayfish, Procambarus clarkia. Fish Shellfish Immun 35:46-53.

Elvitigala D.A.S., Whang I., Premachandra H.K.A., Umasuthan N., Oh M.J., Jung S.J., 2012. Caspase 3 from rock bream (Oplegnathus fasciatus): Genomic characterization and transcriptional profiling upon bacterial and viral inductions. Fish Shellfish Immun, 33:99-110.

Halliwell B., 1993. Antioxidant defence mechanisms: from the beginning to the end (of the beginning). Free Radic. Res, 31:261-272.

Jin Y.X., Zheng S.S, Fu Z.W., 2011. Embryonic exposure to cypermethrin induces apoptosis and immunotoxicity in zebrafish (Danio rerio). Fish Shellfish Immun, 30: 1049-1054.

Kim P., Zamora R., Petrosko P., Billiar T.R., 2001. The regulatory role of nitric oxide in apoptosis. Int. Immunopharmacol, 1:1421- 1441.

Li B., Xian J.A., Guo H., Wang A.L., Miao Y.T., Ye J.M., Ye C.X., Liao S.A., 2014. Effect of temperature decrease on hemocyte apoptosis of the white shrimp Litopenaeus vannamei. Aquacult Int. 22:761-774.

Li M.Y., Ding Y., Mua Y.N., Aoa J.Q., Chen X.H., 2011. Molecular cloning and characterization of caspase-3 in large yellow croaker (Pseudosciaena crocea). Fish Shellfish Immun. 30: 910-916.

Livak K.J., Schmittgen T.D., 2001. Analysis of relative gene expression data using real time quantitative PCR and the $2^{-\triangle \Delta C T}$ method. Methods, 25: 402-408.

Lu J., Moochhala S., Shirhan M., Ng K.C., Tan M.H., Teo A.L., Ling E.A., 2003. Nitric oxide induces macrophage apoptosis following traumatic brain injury in rats. Neurosci. Lett. 339: 147-150.

Mai W.J., Yan J.L., Wang L., Zheng Y., Xin X.Y., Wang W.N., 2010. Acute acidic exposure induces p53-mediated oxidative stress and DNA damage in tilapia (Oreochromis niloticus) blood cells. Aquat. Toxicol. 100: 271-281.

Majumdar T., Chattopadhyay P., Saha D.R., Sau S., Mazumder S.,2009. Virulence plasmid of Aeromonas hydrophila induces macrophage apoptosis and helps in developing systemic infection in mice. Microb. Pathogenesis, 46, 98-107.

Marriott H.M., Ali F., Read R.C., Mitchell T.J., Whyte M.K., Dockrell D.H., 2004. Nitric oxide levels regulate macrophage commitment to apoptosis or necrosis during pneumococcal infection. FASEB J. 18: 1126-1128.

Moine P., Abraham E., 2004. Immunomodulation and sepsis: impact of the pathogen. Shock 22, 297-308.

Orreniu S., Zhivotovsky B., Nicotera P., 2003. Regulation of cell death: the calcium-apoptosis link. Nat. Rev. Mol. Cell Biol. 4, 552-565. 
Pavanelli W.R., Gutierrez F.R.S., Silva J.J.N.V., Costa I.C., Menezes M.C.N.D., 2010. The effects of nitric oxide on the immune response during giardiasis. Braz. J. Infect. Dis. 14: 1413-8670.

Qi Z.H., Liu Y.F., Luo S.W., Chen C.X., Liu Y., Wang W.N., 2013. Molecular cloning, characterization and expression analysis of tumor suppressor protein p53 from orange-spotted grouper, Epinephelus coioidesin response to temperature stress. Fish Shellfish Immun. 35, 1466-1476.

Rizzuto R., Pinton P., Ferrari D., Chami M., Szabadkai G., Magalhães P.J. 2003. Calcium and apoptosis: facts and hypotheses. Oncogene, 53: 8619-8627.

Sahu S., Das B.K., Mishra B.K., Pradhan J., Sarangi N., 2007. Effect of Allium sativum on the immunity and survival of Labeo rohita infected with Aeromonas hydrophila. J. Appl. Ichthyol, 23: 80-86.

Shao J.Z., Liu J., Xiang L.X., 2004. Aeromonas hydrophila induces apoptosis in Carassius auratus lymphocytes in vitro. Aquaculture, 229: 11-23.

Shen Y.B., Zhang J.B., Xu X.Y., Fu J.J., Li J.L., 2013. A new haplotype variability in complement $\mathrm{C} 6$ is marginally associated with resistance to Aeromonas hydrophila in grass carp. Fish Shellfish Immun, 34: 1360-1365.

Singh N.N., Srivastava A.K., 2010. Haematological parameters as bioindicators of insecticide exposure in teleosts. Ecotoxicology, 19: 838-854.

Stevenson R.M.W. 1988. Vaccination against Aeromonas hydrophila. In: Ellis, A.E. (Ed.), Fish Vaccination. Academic Press, London, pp. 112-123.

Tafalla C., Coll J., Secombes C.J., 2005. Expression of genes related to the early immune response in rainbow trout (Oncorhynchus mykiss) after viral haemorrhagic septicemia virus (VHSV) infection. Dev. Comp. Immunol, 29: 615626.

Tellez-Bañuelos C.M., Santerre A., Casas-Solis J., Zaitseva G., 2010. Endosulfan increases seric interleukin-2 like (IL-2L) factor and immunoglobulin $M$ (IgM) of Nile tilapia (Oreochromis niloticus) challenged with Aeromona hydrophila. Fish Shellfish Immun, 28: 401-405.

Thompson C.B., 1995. Apoptosis in the pathogenesis and treatment of disease. Science 267: 1456-1462.

Vázquez G.R., Guerrero G.A., 2007. Characterization of blood cells and hematological parameters in Cichlasoma dimerus (Teleostei, Perciformes). Tissue Cell 39: 151-160.

Wang W.N., Zhou J., Wang P., Tian T.T., Zheng Y., Liu Y., 2009. Oxidative stress, DNA damage and antioxidant enzyme gene expression in the Pacific white shrimp, Litopenaeus vannamei when exposed to acute pH stress. Comp. Biochem. Physiol. C 150: 428-435.

Wang X.L., Cai J.L., Zhang J.L., Wang C.G., Yu Y., Chen Y.X., Zuo Z.H., 2008. Acute trimethyltin exposure induces oxidative stress response and neuronal apoptosis in Sebastiscus marmoratus. Aquat. Toxicol 90: 58-64.

Weinrauch Y., Zychlinsky A., 1999. The induction of apoptosis by bacterial pathogens. Annu. Rev. Microbiol 53: 155-187.

Xian J.A., Wang A.L., Tian J.X., Huang J.W., Ye C.X., Wang W.N., 2009. Orphologic, physiological and immunological changes of haemocytes from Litopenaeus vannameitreated by lipopolysaccharide. Aquaculture 98:139-145.

Xian J.A., Wang A.L., Ye C.X., Chen X.D., Wang W.N., 2010. Phagocytic activity, respiratory burst, cytoplasmic free- $\mathrm{Ca}^{2+}$ concentration and apoptotic cell ratio of haemocytes from the black tiger shrimp, Penaeus monodon under acute copper stress. Comp. Biochem. Phys. C152: 182-188.

Xian J.A., Miao Y.T., Li B., Guo H., Wang A.L.,2013. Apoptosis of tiger shrimp (Penaeus monodon) haemocytes induced by Escherichia coli lipopolysaccharide. Comp. Biochem. Phys. A 164: 301-306. 
Xiang L.X., Peng B., Dong W.R., Yang Z.F., Shao J.Z., 2008. Lipopolysaccharide induces apoptosis in Carassius auratus lymphocytes, a possible role in pathogenesis of bacterial infection in fish. Dev. Comp. Immun 32: 992-100.

Xu X.Y., Shen Y.N., Fu J.J., Liu F., Guo S.Z., Yang X.M., 2012. Matrix metalloproteinase 2 of grass carp Ctenopharyngodon idella (CiMMP2) is involved in the immune response against bacterial infection. Fish Shellfish Immun 33: 251-257. 